\title{
Optimization of Composition of Selected Biomass for Briquette Production
}

\author{
Chukwuneke J. L. ${ }^{1, *}$, Umeji A. C. ${ }^{1}$, Sinebe J. E. ${ }^{2}$, Fakiyesi O. B. ${ }^{3}$ \\ ${ }^{1}$ Department of Mechanical Engineering, Nnamdi Azikiwe University, Awka, Nigeria \\ ${ }^{2}$ Department of Mechanical Engineering, Delta State University, Abraka, Nigeria \\ ${ }^{3}$ Department of Industrial/Production Engineering, Nnamdi Azikiwe University, Awka, Nigeria
}

Received March 27, 2020; Revised May 7, 2020; Accepted May 27, 2020

Copyright (C2020 by authors, all rights reserved. Authors agree that this article remains permanently open access under the terms of the Creative Commons Attribution License 4.0 International License

\begin{abstract}
In this study, investigations were carried out on the energy evaluation, performance analysis and optimization of briquettes produced from biomass wastes (rice-husk and sawdust) and their composites using starch and clay as binders. The proximate compositions of the briquettes were determined following ASTM analytical methods. The moisture content of rice husk and sawdust before briquettes was $20 \mathrm{wt} . \%$ and $15 \mathrm{wt}$ \% respectively. The briquettes produced from bio-waste material of homogeneous particle sizes of $0.5 \mathrm{~mm}$ and two binders of a percentage of 90:10 which were sun-dried, prepared and moisturized, were reduced to 5wt.\% and compressed for the production of briquettes. The energy evaluation of the briquettes was performed using an oxygen bomb calorimeter and the performance test of the briquettes was carried out. Design Expert Central Composite Design Tool was used in the design and Response surface methodology was used to optimize the energy values of rice-husk/sawdust composite briquettes with clay and starch as binders, after which composite briquette made of mahogany sawdust/rice-husk were produced using the optimum condition values of $15 \%$ binder starch, $28 \%$ rice-husk and 9Mpa compaction pressure. The results showed that composite briquettes of mahogany sawdust and rice-husk produced with starch had a maximum energy value of $5.69 \mathrm{kcal} / \mathrm{g}$, while those made with clay had a minimum energy value of $3.35 \mathrm{kcal} / \mathrm{g}$. However, the experimental result was less than the predicted optimum value of $2 \%$. This shows that composite briquette made from mahogany sawdust/rice-husk has better energy efficiency than other briquettes considered and it has been observed that starch is a better bonding material than clay. Briquetting technology has great potential to transform waste biomass in affordable, effective and environmentally safe, high-quality solid fuel for households and industry use.
\end{abstract}

Keywords Energy, Biomass, Binders, Briquettes,
Calorific Value, Composite, Optimization

\section{Introduction}

The world has now gone deep into research to find lowcost methods of recycling waste materials into useful products. The reason is the energy demand which is on the rise and the high energy content of these waste materials. In developing countries, one of the major rural-urban environmental problems is agricultural by-products processing (Yazdani and Hosam, 2010; Chukwuneke et al, 2016). In Nigeria, numerous tonnes of agricultural by-products; sugar cane bagasse, rice husk, maize stalk, groundnut shell, palm kernel shell, etc. are generated annually which amount to the environmental hazard and resulted in air pollution when burnt-off (Achebe et al, 2019; Imeh et al, 2017; Babajide et al, 2018). Some of these agricultural wastes (by-products) may perhaps be utilized (Arevalo et al, 2018; Chukwuneke et al, 2019) and they have values. Agricultural processing of these by-products can be transformed into valuable products; briquettes which provide vital substitute sources of energy for domestic use (i.e. cooking fuel). Out of 7.63 billion persons in the world, an estimate of about 3 billion persons (Babajide et al, 2018) relies upon kerosene, wood, coal and biomass for domestic cooking (Chukwuneke et al, 2016). The conversion of wood waste, coaldust and agricultural by-products to lofty energy briquettes for drying and cooking are possible (Imeh et al, 2017; Akande and Olorunnisola, 2018).

Biomass itself is much in demand by many people all over the world (Zannikos et al, 2012; Willyanto et al, 2017). It has been observed that biomass is an alternative energy that can replace fossil fuels in the future (Kaur et al, 2017; 
Nasir et al, 2019). The exploits of biomass fuel; composite sawdust and briquette been established as the high-quality basis of renewable energy for household cooking (Aina, et. al, 2009; Emerhi et al, 2011; Mungale et al, 2016). The extensive diversity uses of briquettes range from household to industrial and for high-pressure briquette, the sawdust, rice husk and woody residues are the most excellent materials (Achebe et al, 2018; Abdulrasheed et al, 2015) for the reason that they have a high percentage of lignin. However, the majority of parched agricultural residues can be utilized if grounded into an uncouth powder (Oladeji, 2012; Onuegbu et al, 2012). Some make good briquette when mixed with woody biomass to offer the lignin (Raju et al, 2014; Okwu et al, 2018).

The significance of sawdust along with rice husk at the same time as a source of fuel cannot be overstated as it is willingly available and economical (Arevalo et al, 2018).In Nigeria, it is most frequently discarded or scalded off at sawmill sites, hence lots of energy is being wasted and unrestrained heat generated (Achebe et al, 2018; Babajide et al, 2018). Sawdust has been utilized over the years in support of the production of heat and power in gasification of plants and for household cooking (Shekhar, 2011; Shyamalee et al, 2015). This likelihood increases the issue of how superlative to employ this economical waste (Akande and Olorunnisola, 2018). Thus, this paper investigated and optimized the energy values of diverse compressions of rice husk and sawdust briquettes production. However, a review of binders for different briquettes was carried out before quantifying the energy values of the sawdust briquette.

\section{Materials and Methods}

\subsection{Materials}

The materials used are Rice Husk and sawdust (Mahogany, Oak, Gmelina Arborea). These materials were obtained from Ugboka Rice Mill and Timber wood market, Enugu, Nigeria. The binders used were clay and cold-water starch.

\subsection{Methods}

\subsubsection{Raw Materials Preparation and Characterization}

The rice husk and sawdust were arbitrarily collected from sawmills at Ugboka and Timber, Enugu, Nigeria. The percentage moisture content of rice husk and sawdust before briquette was $20 \mathrm{wt} . \%$ and $15 \mathrm{wt} . \%$ respectively. The materials were dried and the moisture content was reduced to $5 \mathrm{wt} . \%$ at a temperature range of $50-100^{\circ} \mathrm{C}$ for about 50 minutes. The samples were sieved to a particle size of $0.5 \mathrm{~mm}$ sieve. The sample percentage weight of $90 \%$ for the different woods, rice husk and $10 \%$ for binder was measured. Twelve different samples were set-up for the experiments; 6 of them are Gmelina, oak, mahogany, Gmelina/mahogany/oak, rice husk, rice husk/Gmelina) for each binder (starch and clay). Group (A) and Group (B) are samples with starch and clay as blenders respectively.

The proximate analysis test was performed using the standard method (ASTM 1992) for determining the percentage of volatile matter content, ash content, fixed carbon. The residual dry sample from the determination of moisture content was preheated for $2 \mathrm{hrs}$ at $250^{\circ} \mathrm{C}$ in a furnace to burn off the volatiles. The resulting sample was heated for $2 \mathrm{hrs}$ at $470^{\circ} \mathrm{C}$ just before the materials turned ashes. The sample weight was calculated and reported to determine the content of volatile matter. The sample was put in the muffle furnace at about $815^{\circ} \mathrm{C}$ for approximately an hour, with about $1 \mathrm{~g}$ in crucible porcelain. Samples were cooled in the desiccator after removal from the furnace, and the weight was taken to assess the ash content. The following formulas (Eq. 1-3) were used to determine the percentage of moisture content, volatile matter content, and ash contents respectively;

$$
\begin{aligned}
\% M C & =\frac{W_{i-W_{f}}}{W_{i-W_{c}}} \times 100 \\
\% V M & =\frac{W_{r d-W_{d s}}}{W_{s t}} \times 100 \\
\% A C & =\frac{W_{b-W_{c}}}{W_{o d}} \times 100
\end{aligned}
$$

Where: $W_{i}, W_{f}$, and $W_{c}$ are the initial weight of the sample plus crucible, weight of sample plus crucible after oven-dry, and weight of the empty crucible respectively; $W_{r d}, W_{d s}$, and $W_{s t}$ are weight due to removal of volatile matter, dry sample after heating, and weight of sample taken respectively; $W_{b}$, and $W_{o d}$ are the weight of the crucible and ash, and oven-dry weight of the sample respectively.

The fixed carbon content of the samples was calculated using the following relation;

$$
\% F C=100 \%-(\% M C-\% A C-\% V M)
$$

Where: FC, MC, AC, and VC are fixed carbon content, moisture content, ash content, and volatile matter content.

The dried bio-wastes have been fed freely into the cylindrical crucible and placed for compression in the briquetting press (WDS 6564201). The piston was manually actuated for 20 counts of hammerhead oscillation to compress the samples for the piston movement. The pressure used for compaction was 9.0MPa. Upon applying the pressure on the material in the die at a time, the briquette shaped was extruded. The briquettes were determined in weight, mass, and diameters.

\subsubsection{Performance Analysis of Briquette}

Ignition and Burning Time: The recommended method of determining the ignition and burning time by Rotich, (1996) was adopted.

Water boiling test: Using a small stainless-steel cup and a domestic briquette bowl, 100g of each briquette 
sample was used to heat and boil $100 \mathrm{~cm}^{3}$ of water (Kaur et al, 2017).

$$
T_{S}=\frac{T}{W_{b}}
$$

Where; $T_{S}, \mathrm{~T}$, and $w_{b}$ are boiling time ( $\mathrm{min} / \mathrm{kg}$ ), total time spent in boiling water, and the total weight of boiled water

Cooking efficiency: The cooking efficiency method given by Madhava et al, (2012); Olatunde et al, (2015) was adopted.

$$
\eta=\frac{M_{w} h_{i}}{M_{f} C_{f}}
$$

Where; $\eta, M_{w}, h_{i}, M_{f}$, and $C_{f}$ are cooking efficiency (\%), the mass of water evaporated $(0.01 \mathrm{~kg})$, heat evaporation of water at atmospheric pressure and temperature of $100^{\circ} \mathrm{C}(2260 \mathrm{~kJ} / \mathrm{kg})$, amount of fuel burnt $(\mathrm{kg})$, and heat value of the fuel used ( $\mathrm{mJ} / \mathrm{kg})$.

Burning Rate: The burning rate method given by Okwu et al, (2018); Olatunde et al, (2015) was adopted.

Burning Rate = mass of fuel consumed/Total time taken

Fuel consumption Rate: The rate which briquettes of various fuel samples were burnt was determined using Madhava et al, (2012); Okwu et al, (2018) method;

$$
M_{f}=\frac{w_{i-w_{f}}}{t}
$$

Where; $w_{i}, w_{f}$, and t are the initial mass of fuel before consumption, the final mass of fuel after consumption, and $t=$ total cooking or boiling time respectively.

\subsubsection{Sawdust Briquettes Energy Content}

The briquettes produced were sun-dry for about 2 days and the average mass of each group sample was determined. The average mass of the group sample was gotten. The bomb Calorimeter was used in determining the calorific value of the briquettes. The calorific values of the briquettes were determined using an oxygen bomb calorimeter according to ASTM standard D-240.

\subsection{Optimization of Galvanized Energy of Biomass Briquettes}

The optimization of the galvanized energy of biomass briquettes was done using the Design Expert Software. Central composite design (CCD), experimental design in Response Surface Methodology (RSM), was used to achieve a second-order (quadratic) model. The design gave rise to 20 Runs with Binder proportion, compaction pressure and proportion of rice husk as the independent variables and the galvanized energy of the biomass briquettes as a response. Five replications of center points were used to predict a good estimation of errors and experiments were performed in a randomized order. The actual and coded levels of each factor are shown in Table (1). The coded values were designated by -1 (minimum), 0 (center), +1 (maximum), $-\alpha$ and $+\alpha$. The empirical equation is represented as shown below:

$\mathrm{Y}=\beta_{0}+\sum_{i=1}^{3} \beta_{i} X_{i}+\sum_{i=1}^{3} \beta_{i i} X^{2}{ }_{i}+\sum_{i=1}^{3} \sum_{j=i+1}^{3} \beta_{i j} X_{i} X_{j}$

Table 1. Factors for Central Composite Design for briquette production

\begin{tabular}{|c|c|c|c|c|c|c|}
\hline Factor & Units & Low level & High level & $-\alpha$ & $+\alpha$ & 0 level \\
\hline Binder proportion (A) & $\%$ & $10(-1)$ & $20(+1)$ & $5(-2)$ & $25(+2)$ & 15 \\
\hline Compaction Pressure (B) & MPa & $6(-1)$ & $12(+1)$ & $3(-2)$ & $15(+2)$ & 9 \\
\hline Proportion of rice husk, RH & $\%$ & $20(-1)$ & $40(+1)$ & $10(-2)$ & $50(+2)$ & 30 \\
\hline
\end{tabular}




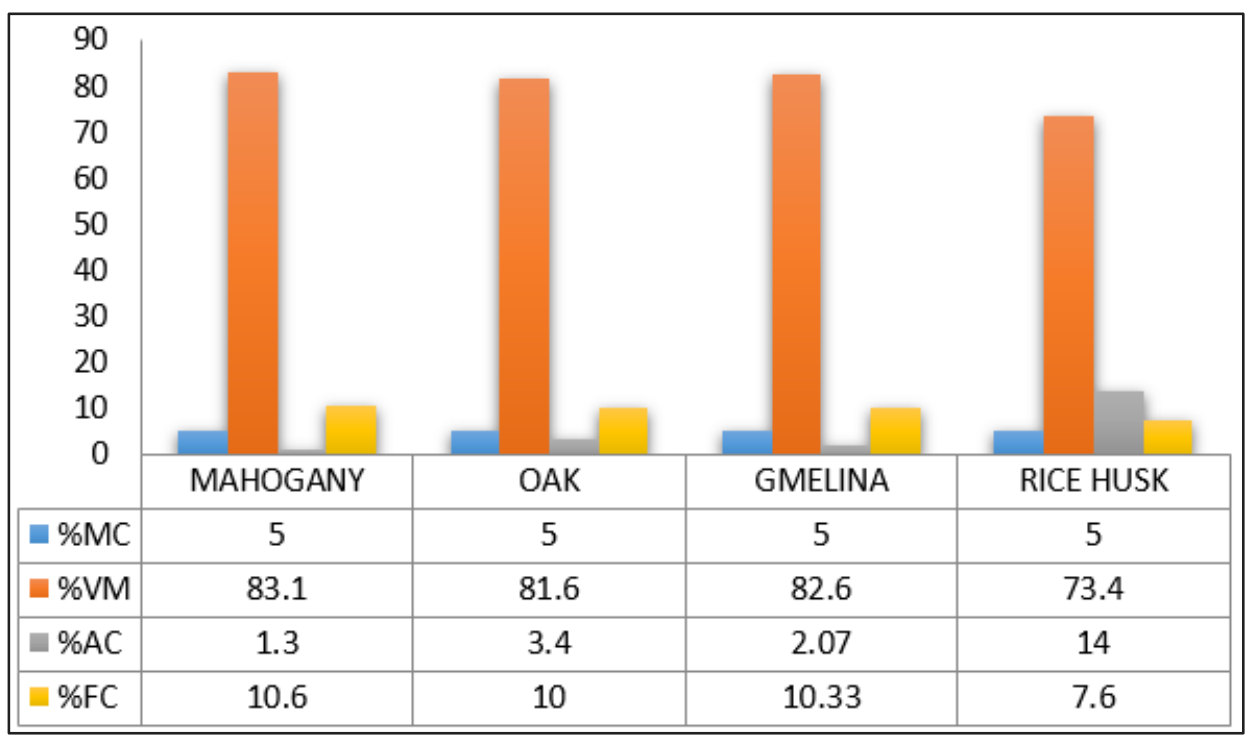

Figure 1. The proximate analysis of the samples

\section{Results and Discussion}

\subsection{Proximate Analysis}

The proximate analysis of all the samples with both binders is presented in figure (1).

Figure (1) indicates the percentage of moisture content of all the samples, ash content, volatile matter content and fixed carbon content. To obtain a standardized value, the moisture content samples were reduced to 5\%. This figure shows that Mahogany sawdust appears stronger for high volatile matter content (83.1\%) followed by Gmelina (82.6\%), Oak (81.6\%) and Rice husk (73.4\%), thus the higher the volatile fuel content, the faster the combustion is, and therefore the burning temperature, as well as the water, tends to be higher (Loo et al, 2008). For Mahogany sawdust, the fixed carbon content $(10.6 \%)$ is the highest compared to other samples such as Oak (10\%), Gmelina (10.33\%), and Rice husk (7.6\%). These results suggest Mahogany sawdust can be exposed to more solid combustion than any other biomass used. Rice husk study showed higher ash content (14\%). Similarly, approximately $3.4 \%$ of Oak sawdust, $2.07 \%$ of Gmelina sawdust and $1.3 \%$ of Mahogany had the lowest value. The highest biomass ash content has the impact of gasifying ash removal from the system. As a result, more Mahogany sawdust combustion produced large amounts of ash relative to other tested fuels, suggesting that this fuel is highly reactive and has high carbon conversion efficiency. The average briquettes made of starch as binder weigh about $75 \mathrm{~g}$ each while the one made of clay as binder weighs about $84 \mathrm{~g}$ each. The average weight, diameter and volume values are $35 \mathrm{~mm}, 70 \mathrm{~mm}$, and $110 \mathrm{~cm}^{3}$ respectively.

\subsection{Statistical and Optimization of the Energy Value of Biomass Briquette Produced from Mahogany Sawdust/Rice Husk Composite with Starch Binder}

The design plan in Table (2) was employed for the statistical analysis and optimization of the energy value of biomass briquette produced from sawdust/rice husk composite using different binders (clay and starch). The variables; binder proportion, compaction pressure and proportion of rice husk on energy value, were optimized using the coded as well as the encoded values of the test variables.

Table 2. Result of Experimental Design Matrix for Optimization of Galvanized Energy

\begin{tabular}{|c|c|c|c|c|c|}
\hline Std & $\begin{array}{c}\text { A: Binder } \\
\text { proportion }\end{array}$ & $\begin{array}{c}\text { B: } \\
\text { Compaction } \\
\text { pressure }\end{array}$ & $\begin{array}{c}\text { C: } \\
\text { Proportion } \\
\text { of RH }\end{array}$ & $\begin{array}{c}\text { GE } \\
\text { for } \\
\text { Clay }\end{array}$ & $\begin{array}{c}\text { GE } \\
\text { for } \\
\text { Starch }\end{array}$ \\
\hline & $\%$ & MPa & $\%$ & kcal/g & $\mathrm{kcal} / \mathrm{g}$ \\
\hline 1 & 10 & 6 & 20 & 2.29 & 3.30 \\
\hline 2 & 20 & 6 & 20 & 3.54 & 4.75 \\
\hline 3 & 10 & 12 & 20 & 3.00 & 4.90 \\
\hline 4 & 20 & 12 & 20 & 2.90 & 3.50 \\
\hline 5 & 10 & 6 & 40 & 2.30 & 2.50 \\
\hline 6 & 20 & 6 & 40 & 3.14 & 4.20 \\
\hline 7 & 10 & 12 & 40 & 3.30 & 4.30 \\
\hline 8 & 20 & 12 & 40 & 2.60 & 3.20 \\
\hline 9 & 5 & 9 & 30 & 1.73 & 3.30 \\
\hline 10 & 25 & 9 & 30 & 2.50 & 3.60 \\
\hline 11 & 15 & 3 & 30 & 2.92 & 2.60 \\
\hline 12 & 15 & 15 & 30 & 3.10 & 3.20 \\
\hline 13 & 15 & 9 & 10 & 3.20 & 3.90 \\
\hline 14 & 15 & 9 & 50 & 2.80 & 2.70 \\
\hline 15 & 15 & 9 & 30 & 3.30 & 5.70 \\
\hline 16 & 15 & 9 & 30 & 3.08 & 5.60 \\
\hline 17 & 15 & 9 & 30 & 3.30 & 5.66 \\
\hline 18 & 15 & 9 & 30 & 3.30 & 5.60 \\
\hline 19 & 15 & 9 & 30 & 3.35 & 5.60 \\
\hline 20 & 15 & 9 & 30 & 3.30 & 5.70 \\
\hline
\end{tabular}


The energy value depends on the significance of the variation of the results from process parameter combinations. The quadratic regression equation developed from the software is seen in Eq. (10). This equation gives the optimum energy value by relating it with the variables in a coded value.

$\mathrm{Y}=5.64+0.078 \mathrm{~A}+0.15 \mathrm{~B}-0.29 \mathrm{C}-0.71 \mathrm{AB}+0.069 \mathrm{AC}+0.056 \mathrm{BC}-$ $0.55 A^{2}-0.69 B^{2}-0.59 C^{2}$

The quadratic model shows how the three factors (A, B and $\mathrm{C}$ ), affects the response (energy value, GE). It comprises of one factor and multi-factor coefficients, which gives the effect of a single factor and the combined effect of different factors respectively. Positive and negative terms represent synergistic and antagonistic effects respectively. From table (3), the sequential model sum of squares gave a large model F-value of 1939.97 which justifies that the proposed quadratic model is adequate. For validation of the adequacy of the model, the statistics test gave a high regression coefficient, $\mathrm{R}^{2}=$ 0.9994 with an adjusted $R^{2}$ value of 0.9989 which is close to the predicted $\mathrm{R}^{2}$ value of 0.9986 . The $\mathrm{CV}$ obtained was $0.91 \%$. Since the "Adeq Precision" of 116.979 is greater than 4 , the signal is thus adequate; hence the design space can be navigated with the model.

Applying the 5\% significance level for The analysis of variance (ANOVA), it can be seen from the table (3) that the terms A, B, C (linear terms), AB, AC, BC (interactive terms) and $A^{2}, B^{2}, C^{2}$ (quadratic terms) are significant, thus the model terms are retained.

The actual and predicted plot in figure (2), gives the correlation between the predicted energy value and the experimental energy value. The close distribution of the points along the straight line indicates agreement between the values of the experimental and predicted responses agree as well as appropriate assumptions for the analysis, hence justifying the quadratic model developed.

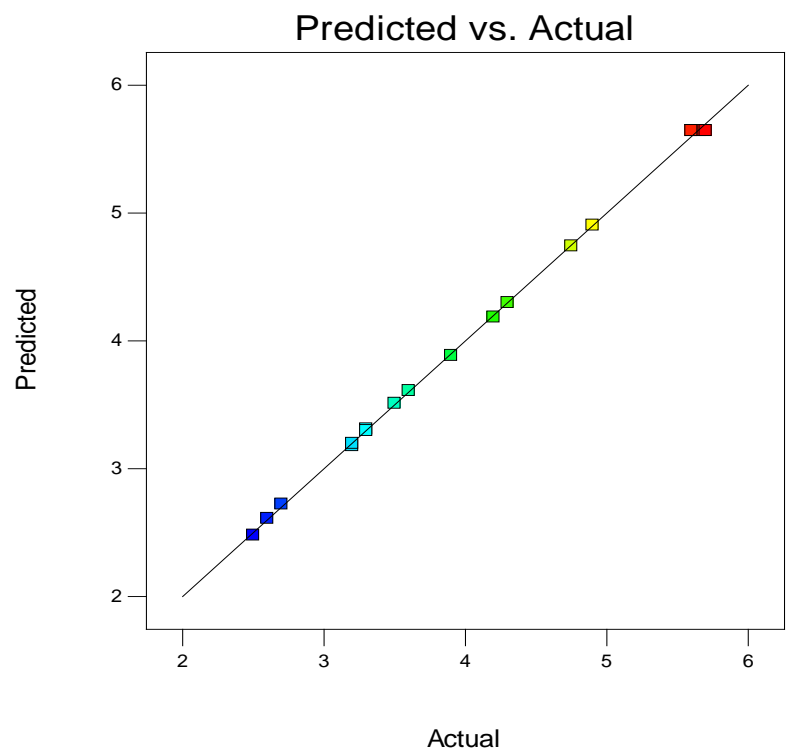

Figure 2. Predicted against actual experimental values for energy value (sawdust/rice husk briquettes with starch binder)

Table 3. Significance of regression coefficients of energy value for sawdust/rice husk briquettes with a starch binder.

\begin{tabular}{|c|c|c|c|c|c|}
\hline Source & Degree of freedom & Sum of square & Mean Square & F-value & P-value (Prob $>$ F) \\
\hline Model & 9 & 25.56 & 2.84 & 1939.97 & $<0.0001$ \\
\hline A & 1 & 0.098 & 0.098 & 66.71 & $<0.0001$ \\
\hline B & 1 & 0.35 & 0.35 & 235.79 & $<0.0001$ \\
\hline $\mathrm{C}$ & 1 & 1.35 & 1.35 & 926.21 & $<0.0001$ \\
\hline $\mathrm{AB}$ & 1 & 3.99 & 3.99 & 2725.98 & $<0.0001$ \\
\hline $\mathrm{AC}$ & 1 & 0.038 & 0.038 & 25.83 & 0.0005 \\
\hline $\mathrm{BC}$ & 1 & 0.025 & 0.025 & 17.29 & 0.002 \\
\hline$A^{2}$ & 1 & 7.54 & 7.54 & 5150.86 & $<0.0001$ \\
\hline$B^{2}$ & 1 & 11.80 & 11.80 & 8062.25 & $<0.0001$ \\
\hline$C^{2}$ & 1 & 8.61 & 8.61 & 5880.46 & $<0.0001$ \\
\hline Residual & 10 & 0.015 & 0.00146 & & \\
\hline Lack of fit & 5 & 0.00231 & 0.00461 & 0.19 & 0.9553 \\
\hline Cor. Total & 19 & 25.57 & & & \\
\hline
\end{tabular}

Std. Dev. = 0.038; Mean = 4.19; C.V.\% = 0.91; PRESS = 0.036; $\mathrm{R}^{2}=0.9994 ;$ Adj. $\mathrm{R}^{2}=0.9989 ;$ Pred. $\mathrm{R}^{2}=0.9986 ;$ Adeq. Precision $=116.979$ 
Figures ( 3,4 \& 5) show the contour and 3D surface plots. They describe how two independent variables combine to affect the energy value.

Figure (3) shows the combined effect that binder composition and compaction pressure have on the energy value. It shows that the energy value increased as both pressure and binder proportion increased until at a point it started decreasing. This could be attributed to higher binder proportion and pressure. Figure (3) shows the interactive effect of the proportion of rice husk and binder proportion on the energy value. It could be seen that the energy value increased as both proportions of rice husk and binder

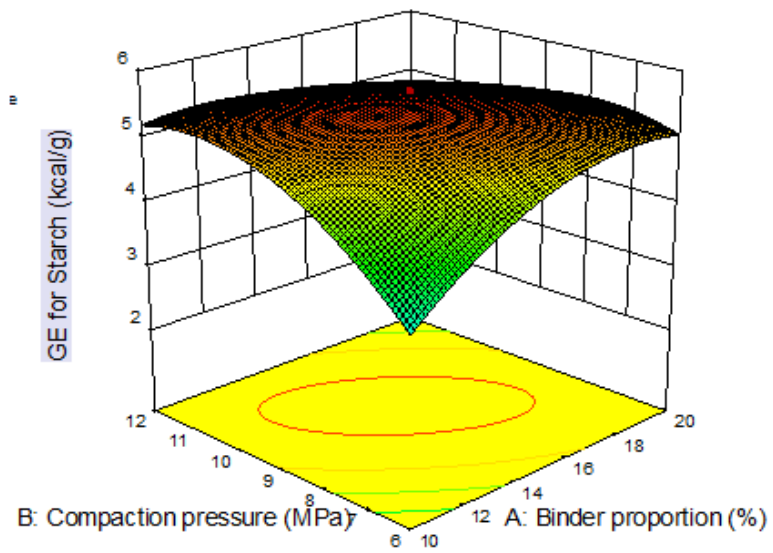

(a)

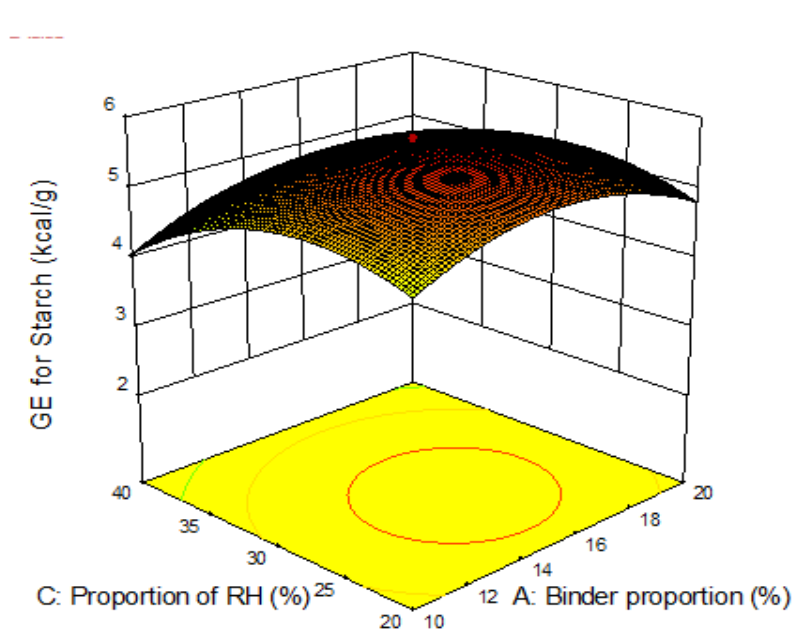

(a) proportion increased until at a point it started decreasing. This could be attributed to a higher proportion of rice husk and compaction pressure.

The optimization process gave a $5.69 \mathrm{kcal} / \mathrm{g}$ energy at optimum 15\% binder proportion, $28 \%$ rice husk proportion and 9MPa compaction pressure. Carrying out a validation experiment to ascertain the justification of the predicted optimum values as seen in the table (4), the experimental result was however less than the predicted value by $2 \%$, thus the developed quadratic model is adequate to predict the energy value. This result is better than the optimized briquette result produced by Kaur et al, (2017).

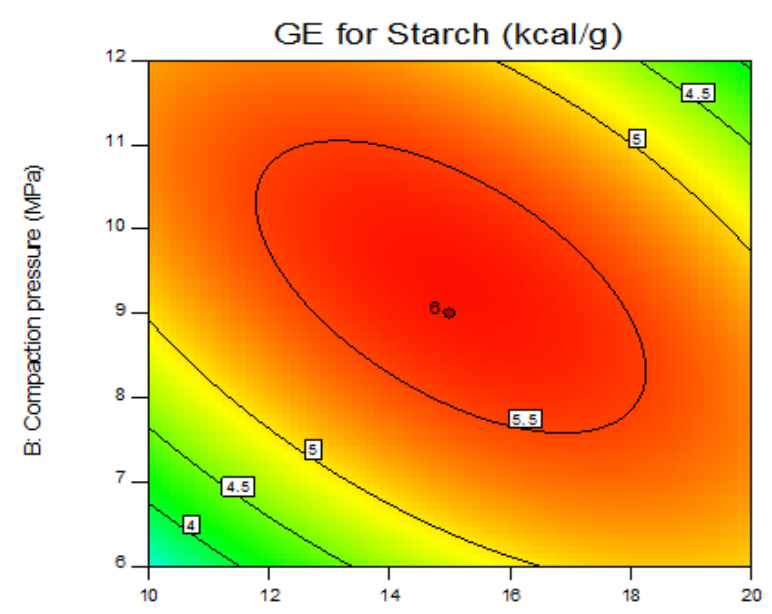

A: Binder proportion (\%)

(b)

Figure 3. Interaction Effects of factors binder proportion and compaction pressure (a) Response surface 3D plot (b) Contour plot

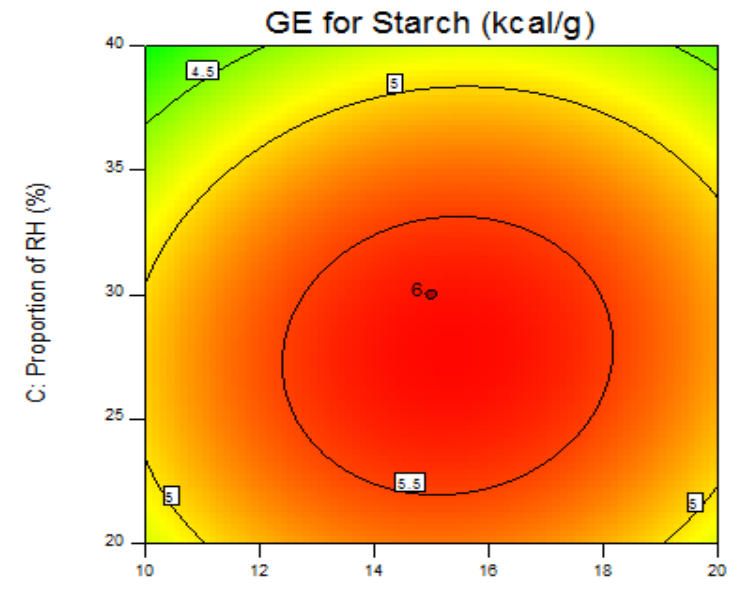

A: Binder proportion (\%)

(b)

Figure 4. Interaction effects of factors binder proportion and proportion of rice husk and binder proportion (a) Response surface 3D plot (b) Contour plot

Table 4. Model validation for energy value of composite briquette produced with a starch binder (experiment to validate the optimum energy value)

\begin{tabular}{|c|c|c|c|c|}
\hline $\begin{array}{c}\text { Binder proportion (\%) } \\
\text { A }\end{array}$ & $\begin{array}{c}\text { Compaction pressure (MPa) } \\
\text { B }\end{array}$ & $\begin{array}{c}\text { Proportion of rice husk } \\
(\%)\end{array}$ & $\begin{array}{c}\text { Experimented energy } \\
\text { value } \\
(\mathrm{kcal} / \mathrm{g})\end{array}$ & $\begin{array}{c}\text { Predicted energy value } \\
(\mathrm{kcal} / \mathrm{g})\end{array}$ \\
\hline 15 & 9.3 & 28 & 5.51 & 5.69 \\
\hline
\end{tabular}


3.3. Statistical and Optimization of the Energy value of Biomass Briquette Produced from Mahogany Sawdust/Rice husk Composite with Clay Binder

Using the design plan shown in table (2), the energy value of biomass briquette produced from mahogany sawdust/rice husk composite with clay binder was analyzed and optimized. The optimization of the variables gave rise to the quadratic model shown in Eq. (11).

$$
\begin{aligned}
& \mathrm{Y}=3.28+0.18 \mathrm{~A}+0.056 \mathrm{~B}-0.074 \mathrm{C}-0.36 \mathrm{AB}- \\
& 0.13 \mathrm{AC}+0.049 \mathrm{BC}-0.29 A^{2}-0.062 B^{2}-0.065 C^{2} \quad(11)
\end{aligned}
$$

The quadratic model shows how the three factors (A, B and C), affects the response (energy value, GE). It comprises of one factor and multi-factor coefficients, which gives the effect of a single factor and the combined effect of different factors respectively. Positive and negative terms represent synergistic and antagonistic effects respectively. From table (5), the sequential model sum of squares gave a large model F-value of 59.95 which justifies that the proposed quadratic model is adequate. For validation of the adequacy of the model, the statistics test gave a high regression coefficient, $\mathrm{R}^{2}=0.9818$ with an adjusted $\mathrm{R}^{2}$ value of 0.9654 which is close to the predicted $\mathrm{R}^{2}$ value of 0.9309 . The $\mathrm{CV}$ obtained was $2.88 \%$. Since the "Adeq Precision" of 30.27 is greater than 4, the signal is thus adequate, hence the design space can be navigated with the model.

Applying the 5\% significance p-value level for the analysis of variance (ANOVA), it can be seen from Table 5 that the terms $\mathrm{A}, \mathrm{B}, \mathrm{C}$ (linear terms), $\mathrm{AB}, \mathrm{AC}$ (interactive terms) and $A^{2}, B^{2}, C^{2}$ (quadratic terms) are significant, thus the model reduces to Eq. (12).
$\mathrm{Y}=3.28+0.18 \mathrm{~A}+0.056 \mathrm{~B}-0.074 \mathrm{C}-0.36 \mathrm{AB}-0.13 \mathrm{AC}-$
$0.29 A^{2}-0.062 B^{2}-0.065 C^{2}$

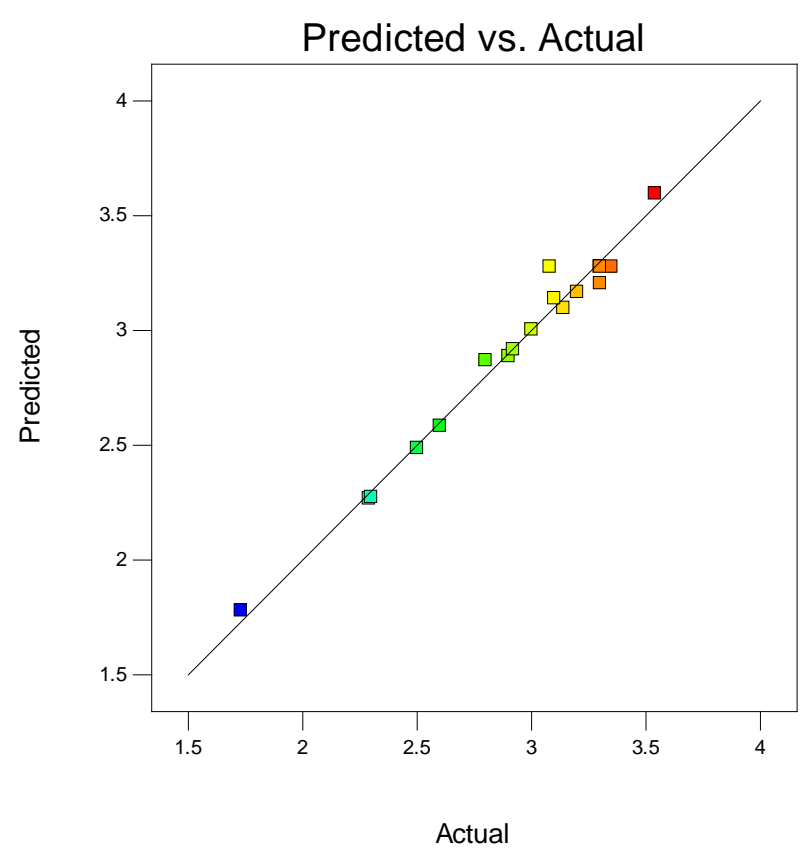

Figure 5. Predicted values versus the actual experimental values for energy value sawdust/rice husk briquettes with a clay binder

The actual and predicted plot in figure (5), gives the correlation between the predicted energy value and the experimental energy value. The close distribution of the points along the straight line indicates agreement between the values of the experimental and predicted responses agree as well as appropriate assumptions for the analysis, hence justifying the quadratic model developed.

Table 5. Significance of regression coefficients of energy value for sawdust/rice husk briquettes with a clay binder

\begin{tabular}{|c|c|c|c|c|c|}
\hline Source & $\begin{array}{c}\text { Degree of } \\
\text { freedom }\end{array}$ & $\begin{array}{c}\text { Sum of } \\
\text { square }\end{array}$ & Mean Square & F-value & P-value (Prob >F) \\
\hline Model & 9 & 3.89 & 0.43 & 59.95 & $<0.0001$ \\
\hline A & 1 & 0.50 & 0.5 & 69.49 & $<0.0001$ \\
\hline B & 1 & 0.05 & 0.05 & 6.87 & 0.0255 \\
\hline C & 1 & 0.089 & 0.089 & 12.29 & 0.0057 \\
\hline AB & 1 & 1.04 & 1.04 & 144.93 & $<0.0001$ \\
\hline AC & 1 & 0.13 & 0.13 & 17.70 & 0.0018 \\
\hline BC & 1 & 0.019 & 0.019 & 2.64 & 0.1353 \\
\hline$A^{2}$ & 1 & 2.06 & 2.06 & 285.55 & $<0.0001$ \\
\hline$B^{2}$ & 1 & 0.098 & 0.098 & 13.54 & 0.0043 \\
\hline$C^{2}$ & 1 & 0.11 & 0.11 & 14.64 & 0.0033 \\
\hline Residual & $\mathbf{1 0}$ & $\mathbf{0 . 0 7 2}$ & 0.0072 & & 0.7281 \\
\hline Lack of fit & $\mathbf{5}$ & $\mathbf{0 . 0 2 6}$ & 0.00519 & 0.56 & \\
\hline Cor. Total & $\mathbf{1 9}$ & $\mathbf{3 . 9 6}$ & & & \\
\hline
\end{tabular}

Std. Dev. = 0.085; Mean = 2.95; C.V.\% = 2.88; PRESS = 0.27; $\mathrm{R}^{2}=0.9818 ;$ Adj. $\mathrm{R}^{2}=0.9654 ;$ Pred. $\mathrm{R}^{2}=0.9309 ;$ Adeq. Precision $=30.27$. 
The combined effect of two independent variables at a time on the energy value is expressed in the contour and 3D surface plots shown in figures ( $6 \& 7$ ). The interaction effect of binder proportion and compaction pressure on the energy value of sawdust/rice husk briquettes produced with clay as a binder is expressed in figure (6). It shows that the energy value increased as both pressure and binder proportion increased until at a point it started decreasing. This could be attributed to higher binder proportion and pressure. Figure (7) shows the interaction effect of the proportion of rice husk and binder proportion on the energy value of mahogany sawdust/rice husk briquettes produced

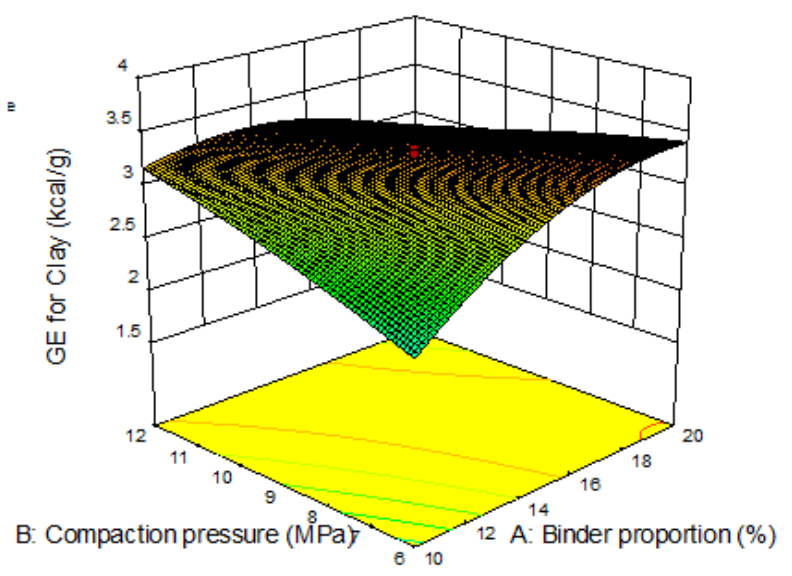

(a) with clay as a binder. It shows that the energy value increased as both the proportion of rice husk and binder proportion increased until at a point it started decreasing. This could be attributed to a higher proportion of rice husk.

The optimization process gave a $3.35 \mathrm{kcal} / \mathrm{g}$ energy at optimum $17 \%$ binder proportion, $26 \%$ rice husk proportion and 9MPa compaction pressure. Carrying out a validation experiment to ascertain the justification of the predicted optimum values as seen in table 6 , the experimental result was however less than the predicted value by $2 \%$, thus the developed quadratic model is adequate to predict the energy value.

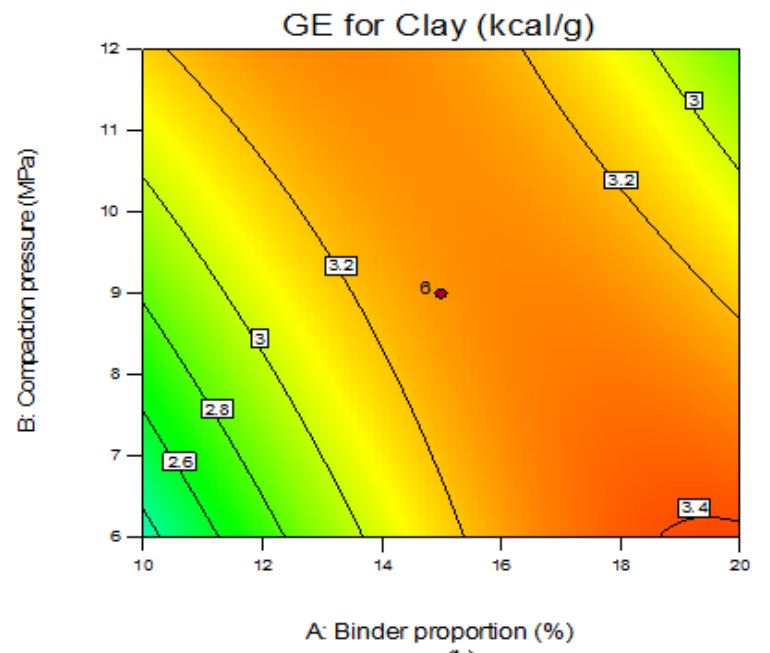

(b)

Figure 6. Interaction effects of factors binder proportion and compaction pressure (a) Response surface 3D plot (b) Contour plot

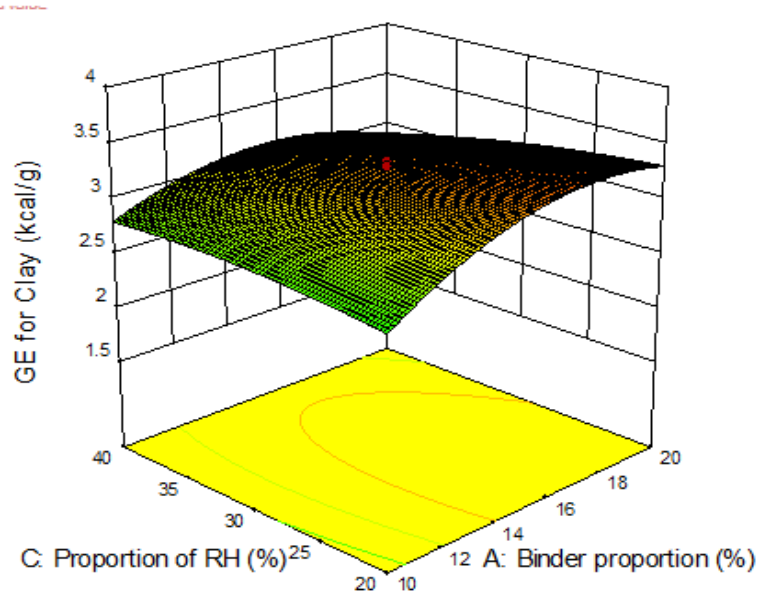

(a)

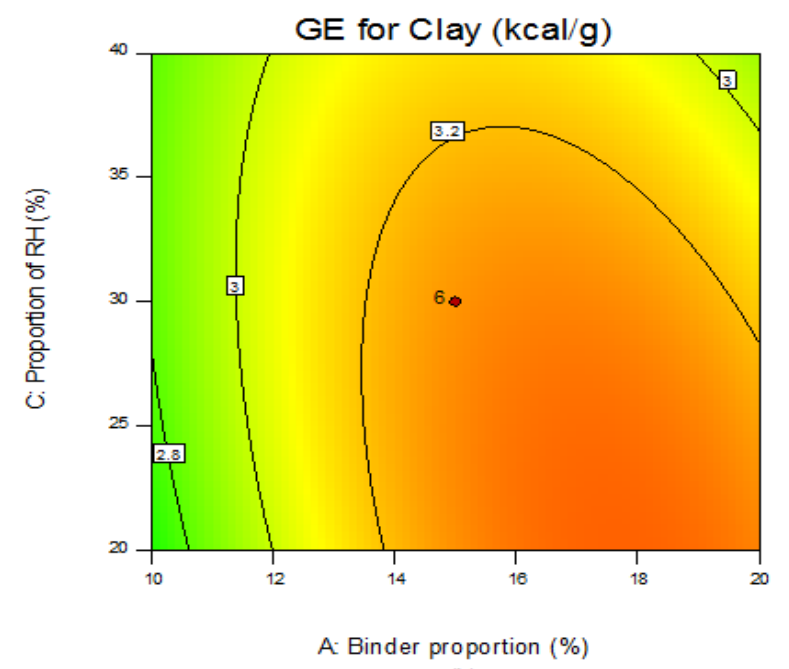

(b)

Figure 7. Interaction effects of factors binder proportion and proportion of rice husk and binder proportion. (a) Response surface 3D plot (b) Contour plot

Table 6. Results of the model validation for energy value of composite briquette produced with clay binder (experiment to validate the optimum energy value)

\begin{tabular}{|c|c|c|c|c|}
\hline $\begin{array}{c}\text { Binder proportion (\%) } \\
\text { A }\end{array}$ & $\begin{array}{c}\text { Compaction pressure (MPa) } \\
\text { B }\end{array}$ & $\begin{array}{c}\text { Proportion of rice } \\
\text { husk }\end{array}$ & $\begin{array}{c}\text { Experimented energy } \\
\text { value } \\
(\mathrm{kcal} / \mathrm{g})\end{array}$ & $\begin{array}{c}\text { Predicted energy value } \\
\text { (kcal/g) }\end{array}$ \\
\hline 17 & 9 & 26.389 & 3.30 & 3.35 \\
\hline
\end{tabular}




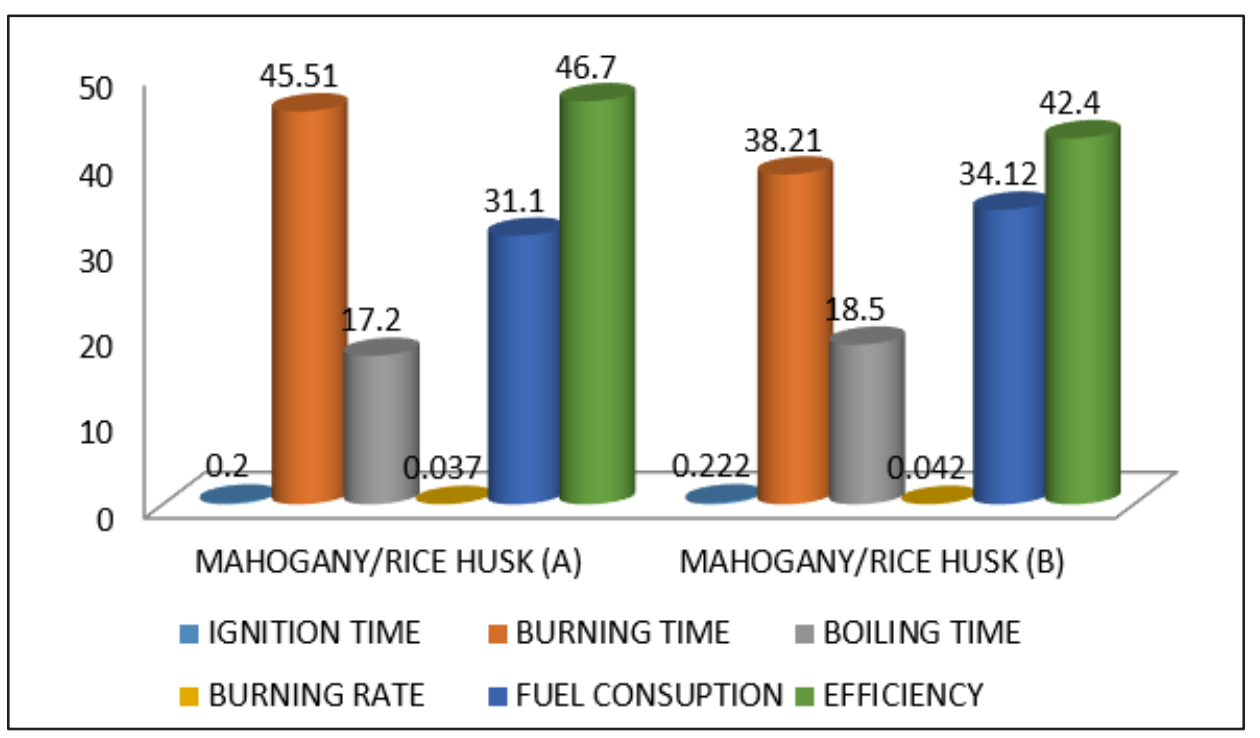

Figure 8. Performance Analysis of Mahogany Sawdust/Rice husk Composite Briquette with Starch and Clay as Binders

\subsection{Performance Analysis of Mahogany Sawdust/Rice husk Composite Briquette}

Results of the Mahogany sawdust/ rice husk composite briquette output analysis using starch and clay as a binder are shown in figure (8).

Figure (8) shows that mahogany sawdust/rice husk composite bonded with starch has a low ignition time (0.2min), high ignition time (45.51min), low ignition time (17.2min), low ignition rate $(0.037 \mathrm{~g} / \mathrm{min})$, low fuel consumption $(31.1 \mathrm{~g} / \mathrm{min})$ and high cooking efficiency (46.7\%) are combined with other briquettes at optimum conditions of $9 \mathrm{Mpa}, 15 \%$ of binder and $28 \%$ of rice husk. In particular, the mahogany briquette bonded with starch, which had previously been listed as the highest before the development of its composite (mahogany sawdust/rice husk). Using sawdust and groundnut shell, this result is better than the briquette provided by Okwu et al, (2018). This performance parameter shows that composite briquette made of mahogany sawdust and rice husk mixed with starch is better compared to when separated because the boiling time and burning rate are lower than others that help to achieve higher efficiency (46.7\%). The result is also better than the briquette provided by Olatunde et al, (2015) using groundnut shell and the difference could be similar to that of Chinyere et al, (2014) as a result of the composite.

\section{Conclusions}

Biomass briquettes have typically demonstrated good prospects as a potential source of fuel. This research was conducted to investigate the properties and performance of briquettes related to the combustion when tested in a wood stove for briquette. The mahogany sawdust was found to have a higher percentage of fixed carbon (10.6\%) and volatile matter (83.1\%), but Rice husk has less fixed carbon
(7.6\%) and volatile matter (73.40). The mahogany sawdust briquette with binder starch yielded $45.7 \%$ higher efficiency while the rice husk briquette with clay as binder yielded $34.7 \%$ lower efficiency. The optimization of the energy values of sawdust (mahogany)/rice husk composite briquettes using starch and clay as a binder was done using response surface methodology (RSM), after which a composite briquette made from mahogany sawdust/rice husk was produced using the optimal condition values (15\% starch, 28\% rice husk and 9Mpa compaction pressure). The results indicated that composite briquettes of mahogany sawdust and rice husk produced using starch gave a higher energy value of $5.69 \mathrm{kcal} / \mathrm{g}$ than that of clay (3.35kcal/g). This shows that briquette from a composite of sawdust (Mahogany)/rice husk is, therefore, more suitable for starting and maintaining fire for cooking and other domestic heating, therefore, it was observed that starch is a better bonding material than clay.

\section{REFERENCES}

[1] Abdulrasheed, A., Aroke, U. O. and Ibrahim, M. (2015). Compression Pressure Effect on Mechanical \& Combustion properties of Sawdust Briquette using Styrofoam adhesive as a binder. American Journal of Engineering Research, 4(8), 205-211.

[2] Achebe CH, Obika EN, Chukwuneke JL and Ani OI (2019). Optimisation of hybridised cane wood-palm fruit fibre frictional material. Proc IMechE Part L. J Materials: Design and Applications, 233 (12), 2490 - 2497. doi: $10.1177 / 1464420719863445$.

[3] Achebe C.H., Umeji A.C., Chukwuneke J.L. (2018). Energy Evaluation of various Compositions of Biomass Waste Briquettes. Advances in Research, 13(6): 1 - 11. 
[4] Aina, O.M., Adetogun, A.C., Iyiola, k. A. (2009). Heat energy from valued-added sawdust briquettes of Albizia Zygia. Ethiopia journal of environmental studies and management .2(1), $42-49$.

[5] Akande O.M. and Olorunnisola A.O. (2018). Potential of Briquetting as a Waste-management Option for Handling Market-Generated Vegetable Waste in Port Harcourt, Nigeria. Recycling, 3(2): 11.

[6] Arevalo P.A., Baggethun E.G., Lopez B.M., Rincon M.P. (2018). Widening the evaluative space for ecosystem services: A taxonomy of plural values and valuation methods. Environmental values, 27(1): 29 - 53.

[7] Babajide P.A., Akinrinnola T.B., Oyeiola Y.B., Okoro-Robinson M.O., Salami T.B., Adesina A., Akindeere A.A. (2018). Performance of Maize (Zea Mays) Grown on Mildly Acidic low Fertile Soil as Affected by Selected Organic-Based Soil Amendments and Synthetic Fertilizer. International Journal of Research-Granthaalayah, 6(9): 385 $-394$.

[8] Chinyere D.C., Asoegwu S.N., Nwandikom G.I. (2014). An Evaluation of Briquettes from Sawdust and Corn Starch Binder. The International Journal of Science \& Technology, 2(7): 147 - 157.

[9] Chukwuneke J.L., Ewulonu M.C., Chukwujike I.C., Okolie P.C. (2019). Physico-chemical analysis of pyrolyzed bio-oil from Swietenia Macrophylla (mahogany) wood. Heliyon, 5: e01790. doi.org/10.1016/j.heliyon.2019.e01790.

[10] Chukwuneke J.L., Azaka O.A., Chukwujike I.C., Sinebe J.E. (2016). Optimization of Waste Management System in Anambra State: A case study of Ifite-Awka. American Journal of Engineering Research, 5(8): 138 - 151.

[11] Chukwuneke J.L., Sinebe J.E., Ugwuegbu D.C. and Agulonu C.C. (2016). Production by Pyrolysis and Analysis of Bio-oil from Mahogany Wood (Swietenia Macrophylla). British Journal of Applied Science \& Technology, 17(4): 1 9.

[12] Emerhi, E.A. (2011), Physical and combustion properties of briquettes produced from sawdust of three hardwood species and different organic binders. Advances in Applied Science Research. 2 (6), 236 - 246.

[13] Imeh E.O., Ibrahim A.M., Aleivo O.A., Stanley I.R.O., Opeoluwa O.F. (2017). Production and Characterization of Biomass Briquettes from Tannery Solid Waste. Recycling, 2(17): 1 - 19.

[14] Kaur A., Kumar A., Singh P., Kundu K. (2017). Production, Analysis and Optimization of low-cost Briquettes from Biomass Residues. Advances in Research, 12(4): 1 - 10.

[15] Loo, S. V., Koppejan, J. (2008). The Handbook of Biomass Combustion and Co-firing. Earth scan, $1^{\text {st }}$ Ed. London. doi.org/10.4324/9781849773041.

[16] Madhava M.P., Koushik B.V.S, Ramesh B.K.R., Srihari R. (2012). Performance Evaluation of a Hand Operated Compression Type Briquetting Machine. Journal of Agricultural Engineering, 49(2): 1 - 9.
[17] Mungale N.P., Awari G.K., Singh M.P., Sakhale C.N. (2016). Model Formulation and Analysis of Total Weight of Briquettes after mixing for Briquette making Operation. International Journal of Energy Research and Applications, 6(3): $25-29$.

[18] Nasir V., Nourlan S., Avramidis S., Cool J. (2018). Classification of thermally treated wood using Machine learning techniques. Wood Science and Technology, doi.org/10.1007/500226-018-1073-3.

[19] Okwu M.O., Samuel O.D., Emovon I. (2018). Production of fuel Briquettes from Hybrid Waste (Blend of Saw-dust and Groundnut shell). Journal of Mechanical Engineering and Technology, 10(2): 1 - 14.

[20] Oladeji, J.T (2012). Comparative Study of Briquetting of Few Selected Agro-Residues Commonly Found in Nigeria.Journal of Science and Technology. 13(2): 80 - 86.

[21] Olatunde A.O., Bukola O.B., Mufutau A.W., Micheal F.A. (2015). Performance Evaluation of Effect of Waste Paper on Groundnut Shell Briquette. Int. Journal of Renewable Energy Development 4 (2): 95 - 101.

[22] Onuegbu, T.U, Ogbu, L.M. and Ejikeme, C. (2012), Comparative Analyses of Densities and Calorific Values of Wood and Briquettes Samples Prepared at Moderate Pressure and Ambient Temperature. International Journal of Plant, Animal and Environmental Sciences. 2(1), 40 - 45.

[23] Raju, A.I, Praveena, U, Satya, M, Jyothi K.R. and Sarveswara, S. (2014). Studies on Development of Fuel Briquettes using Biodegradable Waste Materials. Journal of Bioprocessing and Chemical Engineering, 2(1): 1 - 10.

[24] Rotich P.K. (1996). Carbonization and Briquetting of Sawdust for use in Domestic Cookers. M.Sc. Thesis, Department of Agricultural Engineering, University of Nairobi, Kenya.

[25] Shekhar, N. (2011), Popularization of Biomass Briquettes- A means for Sustainable Rural Development. Asian Journal of Management Research, 2(1): 457 - 473.

[26] Shyamalee D., Amarasinghe A.D.U.S., Senanayaka N.S. (2015). Evaluation of different Binding Materials in forming Biomass Briquettes with Sawdust. International Journal of Scientific and Research Publication, 5(3): $1-8$.

[27] Wilyanto A.S., Fandi D.S., Jovian E. (2017). Biomass Briquette Investigation from Pterocarpus Indicus Leaves Waste as an Alternative Renewable Energy. IOP Conf. Series: Materials Science and Engineering, 241: 012043. DOI:1088/1757-899X/241/1/012043.

[28] Yazdani, M. G. and Hosam M. A. (2010). Properties of Briquette from Agricultural Waste available in Brunei Darussalam and its Environmental Impact. International Scientific Journal. 1 - 8.

[29] Zannikos F.E., Kalligeros S., Anastopoulos G., Lois E. (2012). Converting Biomass and Waste Plastic to Solid Fuel. Journal of Renewable Energy, doi.org/10.1155/2013/36036 8: $1-9$. 